\begin{tabular}{|c|c|c|}
\hline$-7-2$ & $\begin{array}{l}\text { European Association for the } \\
\text { Development of Renewable Energies, Environment } \\
\text { and Power Quality (EA4EPQ) }\end{array}$ & $\begin{array}{l}\text { International Conference on Renewable Energies and Power Quality } \\
\text { (ICREPQ'12) } \\
\text { Santiago de Compostela (Spain), 28th to 30th March, } 2012\end{array}$ \\
\hline
\end{tabular}

\title{
High efficiency energy supply in residential sector using Fuel Cells
}

\author{
J.I. San Martín ${ }^{1}$, I. Zamora ${ }^{2}$, J.J. San Martín ${ }^{1}$, V. Aperribay ${ }^{1}$, P. Eguía ${ }^{2}$, F.J. Asensio ${ }^{2}$, J. García ${ }^{2}$ \\ Department of Electrical Engineering - University of the Basque Country \\ ${ }^{1}$ Escuela de Ingeniería de Eibar \\ Avda. Otaola, 29, 20600 Eibar (Spain) \\ e_mail: joseignacio.sanmartin@ehu.es \\ ${ }^{2}$ Escuela Técnica Superior de Ingeniería de Bilbao
Alda. Urquijo s/n, 48013 Bilbao (Spain)
e_mail: inmaculada.zamora@ehu.es
}

- Analysis of the most favourable combination for micro-cogeneration, including building envelopes, occupancy patterns and climate.

\begin{abstract}
Increasing the overall efficiency of power generation systems has become a priority of research in the field of energy. In this sense, a conventional thermal power plant is able to convert around $33 \%$ of the energy contained in the primary fuel into electricity. The rest of the unused energy corresponds to energy dissipated as heat. By contrast, the overall efficiency of polygeneration systems is within $80-90 \%$ of fuel utilization. This combined production of heat-cold and electricity can be applied in the residential, industrial and service sectors.

Considering the increase in energy efficiency that cogeneration involves, this paper presents an analysis of the possibilities of PEM fuel cells for cogeneration applications. To do this, a set of experimental measurements on a real fuel cell (PEM HP600) has been developed, in order to identify its electrical and thermal aspects, for different loading rates.
\end{abstract}

Key words: Fuel Cells, PEMFC, Cogeneration, Efficiency.

\section{Introduction}

The European Union has considered a priority to promote and develop high-efficiency facilities for the combined production of electricity, heat and cold, in order to save more than $10 \%$ of primary energy, avoiding network losses and reducing emissions. The importance of cogeneration is recognized in European law by European Parliament Directive 2006/32/EC on energy end-use and energy services, which emphasizes the development of a framework of common effort to achieve energy savings of $9 \%$ in 2016.

In Spain, micro-cogeneration and trigeneration are promoted with more favourable rates for the sale of the energy produced. Also, public support up to $30 \%$ exists for promoting high efficiency cogeneration plants, with electrical power lower than $50 \mathrm{~kW}$ (Action Plan 20082012). Moreover, around $25 \%$ of primary energy consumption in some countries is intended for space heating and hot water supply.

Thus, some of the aspects that should be analyzed on the applicability of this technology in providing efficient energy in the tertiary sector are as follows:
- Calculation of the appropriate power generation and thermal storage capacity.

- Design and control of building thermal power plants (thermal storage, auxiliary heating, pumps and heat exchangers) for the maximum utilization of thermal energy.

- Study of impacts on the local grid in case of selling the electricity surplus, i.e. voltage pattern changes, grid congestion, fault level changes, etc.

- Economic dispatch that includes GHG emissions savings.

- Etc.

Furthermore, Directive 2004/88/EC of the European Parliament highlights, among other technologies, high efficiency cogeneration using the technology of fuel cells. In this context, it should be noted that the electrochemical reaction in a fuel cell is exothermic and, therefore, requires refrigeration. This circumstance allows the possibility of cogeneration, allowing to use the heat produced during operation to provide hot water, heating and air conditioning (by absorption systems).

This way, polygeneration systems based on fuel cells are considered really promising, as they are able to achieve very high efficiencies, lower emissions, quiet operation and simple maintenance requirements, compared to conventional systems [1-3].

Fundamentally six types of fuel cells can be considered, where PEMFC, PAFC, MCFC and SOFC, are focused primarily in the field of stationary applications at all levels, including residential ( 1 to $5 \mathrm{~kW})$, commercial (10 to $50 \mathrm{~kW})$ and industrial $(250 \mathrm{~kW}$ to $1 \mathrm{MW})$. As the temperature levels necessary to meet the demands of residential sector are relatively low, PEMFC technology becomes the most appropriate, among the different technologies available for fuel cells [4]. 
In order to accurately assess the overall energy performance of fuel cell in micro-cogeneration applications and optimize the integration and control strategies, this paper presents the experimental results obtained in the laboratory for a real PEM fuel cell (PEM HP600), for their use in power and heat supply in the service sector.

\section{Fuel Cells Characteristics}

Fuel cells are electrochemical devices which directly convert energy from the chemical reaction between a fuel and an oxidant into electrical energy (direct current), releasing water and heat. Figure 1 shows the operating principle of a PEM fuel cell.

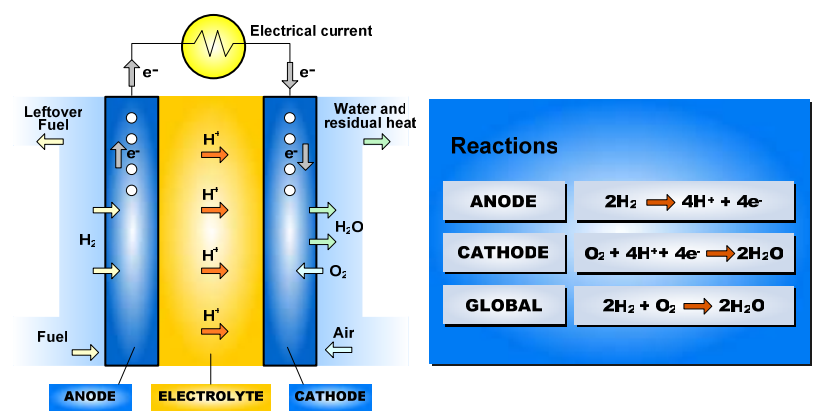

Fig. 1. PEM fuel cell

Some of the innovative features that make them a competitive technology for generating electricity and heat are the following:

- Low environmental impact: The emission of pollutant gases such as $\mathrm{CO}, \mathrm{CO}_{2}$ and $\mathrm{NOx}$ is significantly reduced compared to other systems due to the absence of combustion. Neither emissions of SOx are produced, because the system requires fuel pre-cleaning to avoid contamination of the constituents and increase durability.

- Modular character: Fuel cells are available in separate modules that can be stacked to generate stacks of different sizes and, therefore, of different power, depending on the needs required in each case. This allows automated production, leading to an easier, faster and lower cost construction.

- Flexibility of operation: Flexibility has a dual character, as to the range of application and in terms of fuel used. The modular nature of fuel cells and its possible operation with other fuels different from hydrogen allows a wide range of power, both for stationary uses (hospitals, industrial plants, housing, etc.), and for mobile (transport systems) and portable applications (mobile phones, computers, small appliances, etc.).

- High Efficiency: Fuel cells are not subject to the Carnot cycle, so they are more efficient than any conventional thermal power generation system. Their electrical efficiencies are close to $50 \%$, but if the thermal energy generated (CHP) is taken into account, the overall efficiency can be up to $80 \%$, approximately.
In general, it can be said that among all the available technologies for cogeneration, the development of fuel cells is generating great research opportunities in the area of power generation.

\section{Fuel Cells Theorical Analysis}

In this section a set of expressions that identify the most relevant parameters of PEM fuel cells is presented. In this sense, equations to evaluate voltage, current, power, resistances, electrical and thermal energy and the fuel cell efficiency are shown.

The exit voltage of a simple cell can be represented as expressed in (1) [5].

$$
v_{F C}=E_{N E R N S T}-v_{a c t}-v_{\text {ohmic }}-v_{\text {con }}
$$

where, $E_{N E R N S T}$ is the thermodynamic potential, and $v_{a c t}$, $v_{\text {ohmic }}$ and $v_{\text {con }}$ are the activation, ohmic and concentration overpotential, respectively.

In relation to the reversible voltage of the cell, the value of $\mathrm{E}_{\text {NERNST }}[6]$, is given by (2).

$$
E_{\text {NERNST }}=\frac{\Delta G}{2 F}+\frac{\Delta S}{2 F}\left(T-T_{r e f}\right)+\frac{R T}{2 F}\left[\operatorname{Ln}\left(P_{H_{2}}\right)+\frac{1}{2} \operatorname{Ln}\left(P_{O_{2}}\right)\right]
$$

where: $\Delta G$ is the change in Gibbs free energy $(\mathrm{J} / \mathrm{mol}) ; F$ the Faraday constant; $\Delta S$ the change in entropy $(\mathrm{J} / \mathrm{mol}) ; R$ the universal gas constant; and $P_{H_{2}}$ and $P_{\mathrm{O} 2}$ the partial pressures of hydrogen and oxygen (atm), respectively. $T$ is the fuel cell operation temperature $(\mathrm{K})$, and $T_{\text {ref }}$ the reference temperature.

Equation (3) can be simplified by using standard values for $\Delta G, \Delta S$ and $T_{\text {ref }}[7]$.

$$
\begin{aligned}
& E_{\text {NERNST }}=1.229-0.85 \cdot 10^{-3}(T-298.15) \\
& +4.31 \cdot 10^{-5} \cdot T\left[\operatorname{Ln}\left(P_{\mathrm{H}_{2}}\right)+\frac{1}{2} \operatorname{Ln}\left(P_{\mathrm{O}_{2}}\right)\right]
\end{aligned}
$$

Besides, to consider the dynamic model of the fuel cell, the phenomenon called charge double layer has to be taken into account [8]. The differential equation that allows to obtain the dynamic response is represented by (4).

$$
\frac{d v_{d}}{d t}=\frac{1}{C} i_{F C}-\frac{1}{\tau} v_{d}
$$

where: $v_{d}$ represents the dynamic voltage of the fuel cell, $i_{F C}$ is the fuel cell current, $C$ is the equivalent electric capacity (F) and $\tau$ is the electric time constant (s), defined by (5).

$$
\tau=R_{a} C=C\left(R_{a c t}+R_{c o n}\right)=C\left(\frac{v_{a c t}+v_{c o n}}{i_{F C}}\right)
$$

where $R_{a}$ represents the equivalent resistance.

Besides, the membrane equivalent resistance can be calculated by (6). 


$$
R_{M}=\frac{\rho_{M} \cdot l}{A}
$$

where: $\rho_{M}$ is the membrane specific resistivity to the flow of electrons $(\Omega \cdot \mathrm{cm}) ; A$ is the active cell area $\left(\mathrm{cm}^{2}\right)$ and $l$ is the membrane thickness $(\mathrm{cm})$. The value of the specific resistivity can be obtained from [6].

From (6), the ohmic voltage drop can be calculated, using (7).

$$
v_{\text {ohmic }}=i_{F C}\left(R_{M}+R_{C}\right)
$$

where, $R_{C}$, is the resistance to the transference of protons through the membrane, usually constant.

Assembling terms, it is possible to define the voltage of the fuel cell by means of (8).

$$
v_{F C}=E_{\text {NERNST }}-v_{d}-v_{\text {ohmic }}
$$

Moreover, for a fuel cell stack fed with pure hydrogen, the fuel consumption can be obtained by means of (9).

$$
\dot{m}_{H_{2}}=1.05 \cdot 10^{-8} \cdot \frac{P_{s}}{v_{F C}}
$$

where: $\dot{m}_{\mathrm{H}_{2}}$ is the hydrogen mass flow rate $(\mathrm{kg} / \mathrm{s}) ; v_{F C}$ is the fuel cell voltage $(\mathrm{V})$, and $P_{s}$ is the electric power of the stack (W) obtained from the expression (10).

$$
P_{s}=n \cdot v_{F C} \cdot i_{F C}
$$

being $n$ the number of cells, in series connection, that are used to constitute the fuel cell stack.

Additionally, the air mass flow rate $(\mathrm{kg} / \mathrm{s})$ can be obtained by using expression (11).

$$
\dot{m}_{\text {air }}=3.57 \cdot 10^{-7} \cdot \lambda \cdot \frac{P_{s}}{v_{F C}}
$$

where $\lambda$ is the stoichiometric rate.

In addition, the rate of water production $(\mathrm{kg} / \mathrm{s})$, during the operation of the stack, can be calculated through expression (12).

$$
\dot{m}_{\mathrm{H}_{2} \mathrm{O}}=9.34 \cdot 10^{-8} \cdot \frac{P_{s}}{v_{F C}}
$$

Most of the variables seen up to now depend on the operation pressure and temperature. The variation of these operating conditions directly affects the operation of the fuel cell. At higher operation temperatures and pressures, the fuel cell voltage will be increased, as well as its efficiency, for a certain current value.

The operation temperature of a fuel cell can be obtained by using equation (13).

$$
M \cdot C_{s} \frac{d T}{d t}=\Delta \dot{Q}
$$

where $M$ is the mass of the cell $(\mathrm{kg}) ; C_{s}$ is the equivalent average specific heat coefficient $(\mathrm{J} / \mathrm{kgK})$ and $\Delta \dot{Q}$ is the rate of heat variation $(\mathrm{J} / \mathrm{s})$.

The value of $M \cdot C_{s}$ must be computed as the sum of the products of the individual masses and heat coefficients corresponding to all cell components (as with graphite and iron, for example).

The heat variation ratio is computed as the difference between the heat rate generated during the fuel cell operation and the heat rate removed by the cooling system, as it is represented by expression (14).

$$
\Delta \dot{Q}=\dot{Q}_{g e n}-\dot{Q}_{r e m}
$$

Finally, the rate of heat generation by the fuel cell can be obtained by means of expression (15).

$$
\dot{Q}_{\text {gen }}=P_{s}\left(\frac{1}{\eta_{F C}}-1\right)
$$

where $P_{s}$ is the electric power provided by the fuel cell (W) and $\eta_{F C}$ is its efficiency, obtained from expression (16).

$$
\eta_{F C}=\frac{P_{s}}{m_{H_{2}} \cdot L H V_{H_{2}}}
$$

where: $\dot{m}_{H_{2}}$ is the hydrogen mass flow rate $(\mathrm{kg} / \mathrm{s})$ and $L H V_{H 2}(\mathrm{~J} / \mathrm{kg})$ is the hydrogen low heating power.

\section{Residential Cogeneration Systems with PEMFC}

In traditional residences, electricity is supplied from the main grid and hot water is supplied primarily by a gas water heater. In order to achieve high energy efficiency in the overall installation, an efficient use of electricity and hot water is required. One solution is to use PEM fuel cell devices.

In the PEM fuel cell, a circuit is inserted to extract the heat generated by the electrochemical reaction, thus maintaining the temperature within the optimum range. The heat extracted through the internal cooling circuit is collected through a series of exchangers that deliver it to an external circuit, producing hot water or steam (depending on the operating temperature of the fuel cell) and increasing the system efficiency.

Figure 2 shows an example of residential cogeneration system based on a PEM fuel cell [9]. Besides, Figure 3 shows the configuration of a PEMFC cogeneration system, which consists of two subsystems: 
- $\quad$ A PEMFC, which is composed by a fuel processing system (FPS), a fuel cell stack and an inverter for grid connection.

- An exhaust gas heat recovery unit (EHU), consisting of an auxiliary boiler and a storage tank.

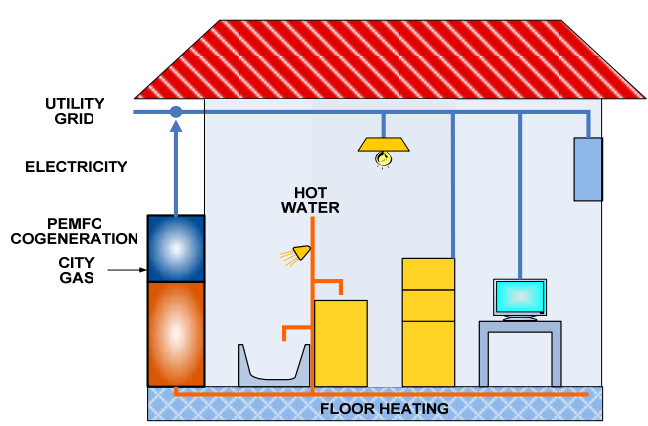

Fig 2. Scheme of residential cogeneration system based on PEMFC

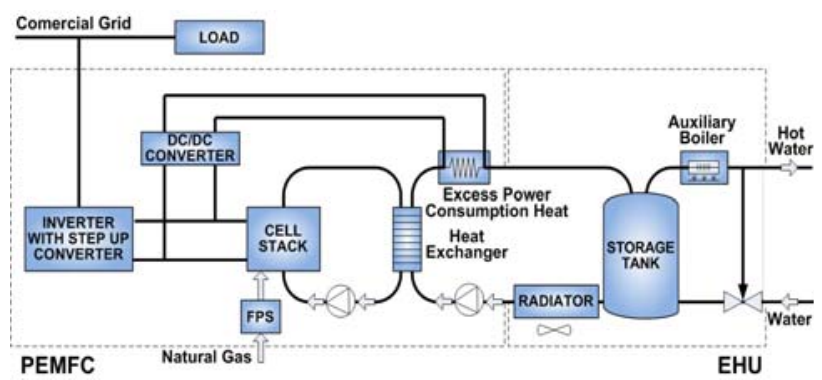

Fig. 3. Configuration of PEMFC cogeneration system

The basic operation of this system is as follows. The FPS reforms city or liquefied gas into hydrogen. Hydrogen reacts with oxygen in the fuel cell to generate electricity, heat and water. The electricity generated is converted into alternate current by a grid connected inverter and supplied to the electric load. The thermal energy generated by the FPS and the fuel cell is collected and stored in a hot water storage tank to supply heat demand. Besides, the system has a heater to absorb the excess of electric energy generated.

This heater is necessary because in some countries, i.e. Japan, electrical utilities do not buy the excess power generated by residential cogeneration systems and, consequently, that electricity cannot be injected into the grid. Also, if there is a large heat demand that cannot be covered only by the heat generated by the PEMFC system, when it works only for electrical needs, the system can be programmed to operate generating more electricity and this power excess can be converted into heat, to meet the heat demand. The heater is used instead of an auxiliary boiler, since the heater efficiency is greater.

The system also has a radiator to avoid the coolant temperature to exceed an upper limit. This enables continuous operation even when the storage tank is filled with hot water. Continuous operation prevents negative effects of repetitive stop-start up cycles. A reduction in the number of start-ups with non-continuous operation is necessary to improve the life expectancy of the system [10].

\section{Cogeneration System with PEMFC HP600}

The HP600 fuel cell system is designed to operate with air and hydrogen. A fan, working as compressor, takes air from the atmosphere through a filter and introduces it into the stack of the fuel cell. The hydrogen is injected into the device from the fuel source, through a reducing pressure valve and a quick coupler input [11]. The stack of this PEM fuel cell consists of 24 cells connected in series. Using an electro-chemical reaction, the fuel cell produces electricity and water, which is released to ambient in the form of moist air. The reaction also produces heat, which can be recovered for cogeneration processes.

The power produced is accessible through two external terminals. A small amount of this power is consumed in the internal processes of the fuel cell (auxiliary devices). The rest can be applied to $12 \mathrm{~V} \mathrm{DC}$ external loads that can be connected through a dc/dc converter in order to stabilize the PEM fuel cell output voltage, or $230 \mathrm{~V}$ AC external loads that can be fed through an inverter.

The heat produced in the process is released to a cooling circuit. An electric water pump circulates the water and cools the stack of the fuel cell. The heat is recovered through a heat exchanger.

Figure 4 shows the HP600 module, which integrates a PEM fuel cell and the possibility of taking electrical and thermal measures. This module is connected to an electronic load (EL-1500), which is responsible for power demand. A PC and a grid analyzer is used for registering electrical measurements [11].

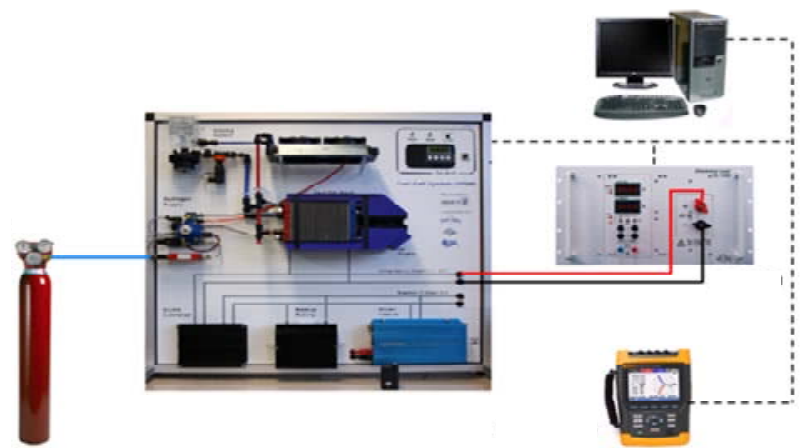

Fig. 4. HP600 system PEM fuel cell

Table 1 shows the most relevant technical data of the HP600 fuel cell system.

Table 1. HP600 Fuel cell system technical data

\begin{tabular}{|c|c|c|c|}
\hline \multicolumn{2}{|c|}{ PEM Type ( 24 cells) } & \multicolumn{2}{|c|}{ DC/DC Converter } \\
\hline Rated net power & $600 \mathrm{~W}$ & Nominal output voltage & $12 \mathrm{VDC}$ \\
\hline DC voltage range & $12-22 \mathrm{~V}$ & Output voltage & $10,5-15 \vee D C$ \\
\hline Rated voltage & 14,4 V DC & Power & $600 \mathrm{~W}$ \\
\hline Rated current & $40 \mathrm{~A}$ & Indigrated charge controller & \\
\hline Rated temperature & $40-60^{\circ} \mathrm{C}$ & \multicolumn{2}{|c|}{ DC/AC Inverter } \\
\hline Pressure & $5-25$ bar & Output voltage & $230 \mathrm{VAC}$ \\
\hline Hydrogen consumption & $7 \mathrm{~N} / \mathrm{min}$ & Power & $700 \mathrm{~W}$ \\
\hline Purity & $5.0(99,999 \%)$ & \multicolumn{2}{|l|}{ Battery } \\
\hline Air supply & Axial Flow Fan & Nominal voltage & $12 \mathrm{VDC}$ \\
\hline \multirow[t]{4}{*}{ Cooling system } & Circulation pump & Capacity & $10 \mathrm{Ah}$ \\
\hline & & Dimension & $1000 \times 1000 \times 400 \mathrm{~mm}$ \\
\hline & $\begin{array}{l}\text { Waterar near } \\
\text { exchanger with } \\
\text { cooling tans }\end{array}$ & Weight & $35 \mathrm{~kg}$ \\
\hline & & Operating conditions & $15-35^{\circ} \mathrm{C}$ \\
\hline
\end{tabular}




\section{Experimental Results}

On this fuel cell cogeneration system (HP600), several experimental measurements have been taken in the laboratory. Following, some examples are shown.

Figure 5 shows the evolution of the current demanded by the electronic load. As can be seen in this figure, rise and fall ramps have the same slope, in order to be able to compare them.

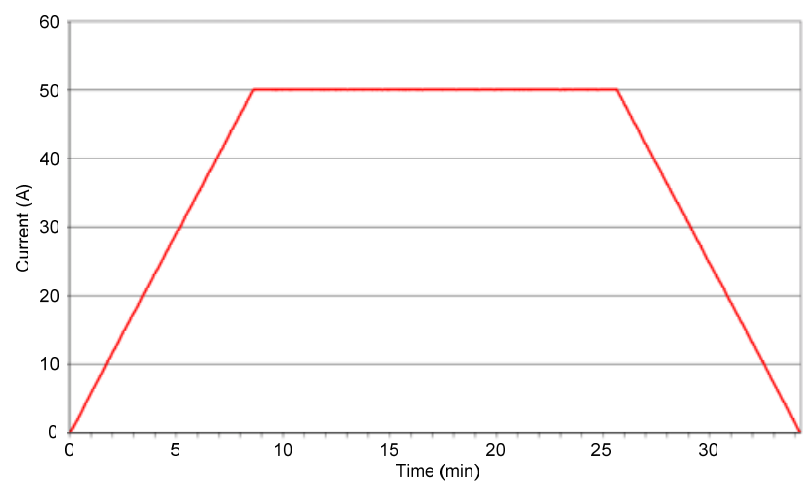

Fig. 5. Current demanded by the electronic load

Figure 6 shows the power consumed by the electronic load. As the figure shows, its shape is similar to the previous current curve, being the highest value of power, approximately, $730 \mathrm{~W}$.

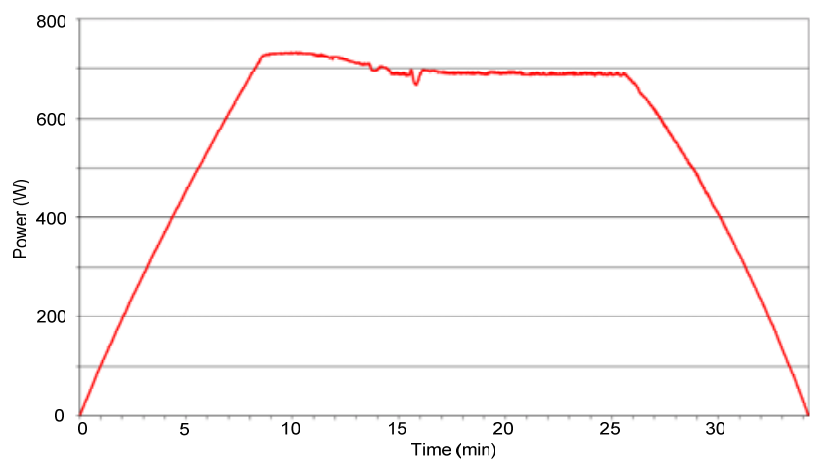

Fig. 6. Power demanded by the electronic load

Figure 7 shows the real consumption of hydrogen in the fuel cell, that is, the hydrogen that has entered into reaction with oxygen from the air compressor. Besides, Figure 8 shows the comparison between the hydrogen flow and its accumulated consumption. It can be seen that the hydrogen consumption slope depends on the hydrogen flow value.

Figure 9 shows the temperature of the stack during the test and how the cooling fan, that refrigerates the stack through the heat exchanger, works. It can be observed that during the rising ramp, the cooling fan does not operate. However, as the stack temperature exceeds $60{ }^{\circ} \mathrm{C}$ (temperature set point) the cooling fan begins to work opposing to the increase in temperature. From the moment that the cooling fan starts operating, the cooling control system tries to keep the stack at a temperature close to $60{ }^{\circ} \mathrm{C}$. When demand decreases, it causes a temperature drop in the stack. It can be seen how the slope of the temperature drop is less significant than the upslope. This is due to thermal inertia.

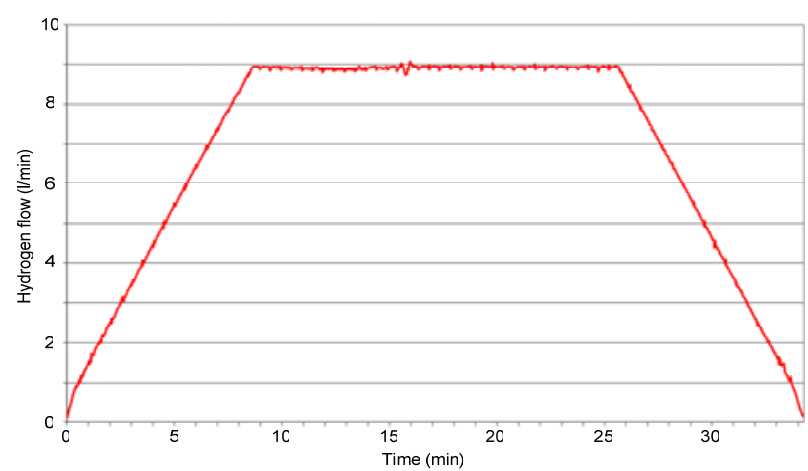

Fig. 7. Real hydrogen flow by HP600 module stack

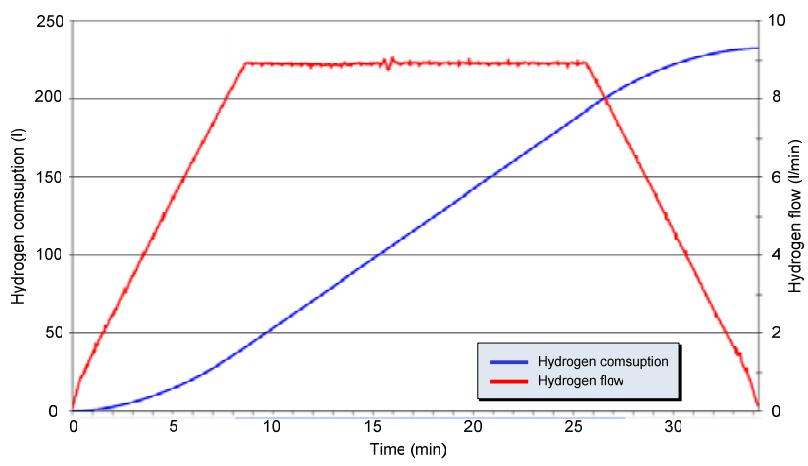

Fig. 8. Real hydrogen flow and accumulated consumption by HP600 module stack

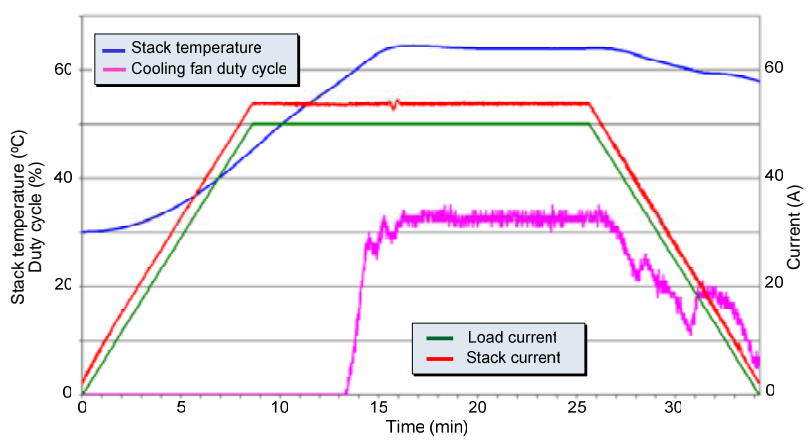

Fig. 9. Stack temperature, cooling fan duty cycle, stack current and load current during the test.

Figure 10 shows the evolution of the stack voltage and hydrogen flow, depending on the stack current, for the rise ramp. It can be seen that in the first zone, from $0 \mathrm{~A}$ to $8 \mathrm{~A}$, the curve has a logarithmic nature associated with the overvoltage activation. For higher currents, the curve presents a linear evolution, determined by the ohmic resistance of the fuel cell. Regarding the flow of hydrogen, it has a linear characteristic, concordant with Faraday's law.

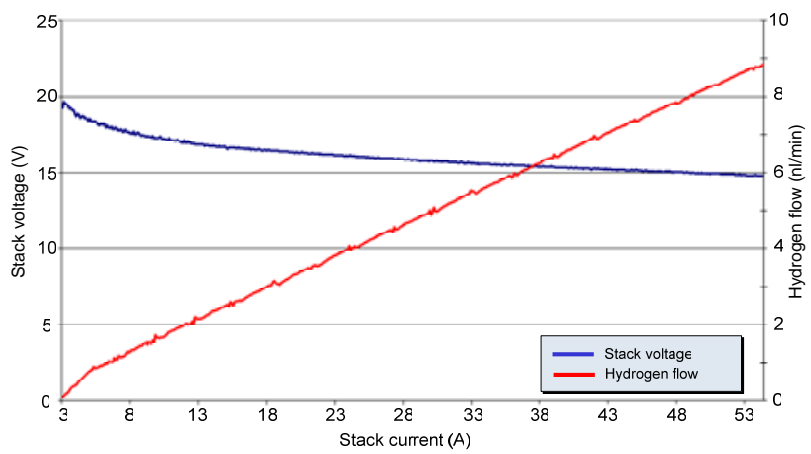

Fig. 10. Stack voltage and hydrogen flow rate of rise ramp depending on the current in the stack 
In Figure 11 the overall efficiency of the fuel cell system and the power supplied to the load and the cooling fan duty cycle are shown. This overall efficiency includes electrical and thermal efficiency. At first, the overall efficiency mainly includes the electrical component, since little heat is removed from the stack. As the stack temperature rises, the cooling fan reduces the temperature of the heat exchanger, extracting more heat from the stack. It is in this range where the overall efficiency increases, due to the thermal energy released from the stack.

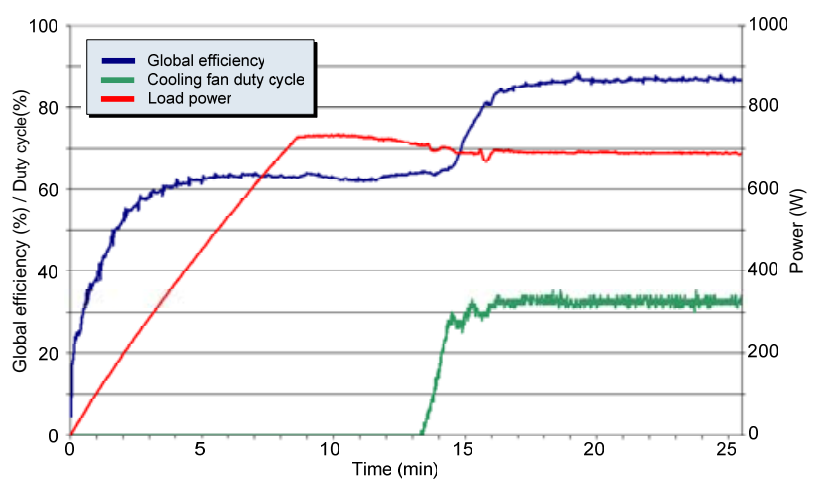

Fig. 11. Overall system efficiency, cooling fan duty cycle and load power

\section{Conclusions}

This paper presents the most relevant results, derived from an experimental analysis, of a real PEM fuel cell system, which allows measuring several electrical and thermal aspects. The objective is to determine the overall efficiency that can be obtained when attempting to provide electricity and heat to buildings in the tertiary sector.

In this context, the fuel cell system has been tested applying rising ramps in current and power, to achieve power values slightly higher than the nominal power. Following, the system is kept providing the maximum power for enough time to allow the stabilization of stack temperature, i.e. it acquires the steady state. This way, the representative curves of the fuel cell system operating in real conditions can be obtained.

Finally, it can be highlighted that an overall efficiency of $87.33 \%$ can be obtained with the HP600 system. This result takes into account an electrical efficiency of $43.18 \%$ and a thermal efficiency of $44.15 \%$.

\section{Acknowledgement}

The work presented in this paper has been supported by the Basque Government (Ref. IT532-10), the Regional Council of Gipuzkoa and the University of the Basque Country (UFI 11/28).

\section{References}

[1] Y.T. Seo, D.J. Seo, J.H. Jeong, W.L. Yoon, “Development of compact fuel processor for $2 \mathrm{~kW}$ class residential PEMFCs", Journal of Power Sources, vol.163, pp.119-124, 2006.

[2] M.B Gunes, M.W Ellis, "Evaluation of energy, environmental, and economic characteristics of fuel cell combined heat and power systems for residential applications", Journal of Energy Resources Technology, vol.125, pp.208-220, 2003.

[3] A. Arsalis, M.P. Nielsen, S.K. Kaer, "Modeling and parametric study of a $1 \mathrm{kWe}$ HT-PEMFC based residential micro-CHP system", International Journal of Hydrogen Energy, vol.36, pp.5010-5020, 2011.

[4] J.I. San Martín, I. Zamora, J.J. San Martín, V. Aperribay, P. Eguía, "Trigeneration Systems with Fuel Cells" ICREPQ-08, Santander.

[5] J.M. Correa, F.A. Farret, L.N. Canha, "An analysis of the dynamic performance of proton exchange membrane fuel cells using an electrochemical model" Proceedings IEEE, IECON'01, pp. 141-146, 2001.

[6] J.M. Correa, F.A. Farret, L.N. Canha, M.G. Simoes, “An Electrochemical-Based Fuel-Cell Model Suitable for Electrical Engineering Automation Approach" IEEE Transactions on Industrial Electronics, vol.51, No.5, pp. 1103-1112, 2004.

[7] R.F. Mann, J.C. Amphlett, M.A.I. Hopper, H.M. Jensen, B.A. Peppley, P.R. Roberge, "Development and application of a generalized steady-state electrochemical model for a PEM Fuel Cell”, Journal Power Sources, vol.86, pp. 173-180, 2000.

[8] J.E. Larminie, A. Dicks, "Fuel Cells Systems Explained", p.308, John Wiley \& Sons, Chichester, U.K., 2003..

[9] K. Kobayashi, M. Kawamura, T. Takahashi, Y. Nishizaka, K. Nishizaki, "PEMFC Project", Technology Development Department, Tokyo Gas Co., Ltd., Japan, 2004.

[10] K. Maeda, K. Masumoto, A. Hayano, "A study on energy saving in residential PEFC cogeneration systems", Journal of Power Sources, vol.195, pp3779-3784, 2010.

[11] HP600 Fuel Cell System User's Manual. 